\title{
An Update on B Vitamin Nutrition for Cattle
}

\author{
K. Ashwin ${ }^{*}$, Varsha Paladan², Sandeep Uniyal ${ }^{1}$, Jatin Kumar Sahoo" ${ }^{1}$, \\ Shahla Perween ${ }^{1}$, Mokshata Gupta ${ }^{1}$ and Asmita Singh ${ }^{1}$ \\ ${ }^{1}$ Animal Nutrition Division, ${ }^{2}$ Veterinary Bacteriology Division, ICAR-Indian Veterinary \\ Research Institute, Bareilly, UP, India \\ *Corresponding author
}

\section{A B S T R A C T}

\section{Keywords \\ health, Ketosis, \\ Laminitis, \\ Microbial \\ fermentation, Milk, \\ Rumen, Stress \\ Article Info \\ Accepted: \\ 04 June 2018 \\ Available Online: \\ 10 July 2018}

B vitamin supplementation in ruminants is ignored conventionally following an earlier observation that they are synthesized in adequate quantities in the rumen by rumen microbes. Recent researchers reported that major cellulolytic organisms in the rumen had specific requirements for certain B vitamins. Apart from the requirements of the rumen microbes, high producing cattle also require a higher amount of vitamins to maintain their productivity and health. Sub-clinical vitamin deficiencies often go unnoticed due to the lack of proper clinical symptoms. The present review aimed at providing an update on B vitamin nutrition to cattle.

\section{Introduction}

B complex vitamins perform a variety of functions in the body. In ruminants, supplementation of $\mathrm{B}$ vitamin is largely debated owing to the general misconception that they are produced in sufficient quantity within the rumen by rumen microbes (Bechdel et al., 1928). The major source of vitamins in dairy cattle is green roughages (Schwab et al., 2006). In the present scenario, there is an acute shortage for high-quality green roughages, especially in the tropics. The major aim of the dairy industry nowadays is to boost milk production. Higher milk production is always associated with higher vitamin requirements as it is utilized for higher metabolism and milk production. This situation produces vitamin deficit in cattle, which often go unnoticed due to lack of visible clinical symptoms. The present review underlines the need to revisit the fundamental concept of vitamin nutrition in dairy cows.

\section{Rumen microbes require specific vitamins}

Baldwin and Allison (1983) reported that all cellulolytic organisms in the rumen hadobligate requirement for biotin. Biotin also improved propionate production by bacteria and thereby glucose availability for the ruminant. In addition, the growth of 
Ruminococcus species was enhanced on supplementation of cyanocobalamin and pyridoxine. Thiamine (Orpin and Greenwood, 1986), riboflavin (Fletcher, 1956), niacin (Niehoff et al., 2013), biotin (Cruyvagen and Bunge, 2004) and pyridoxine (McLeod and Murray, 1956) supplementation improved microbial fermentation in the rumen. This also improved the microbial proliferation and availability of microbial protein for the ruminants.

\section{B complex vitamins improved health in ruminants}

Sato et al., (1999) reported improvement in the neutrophil function and reduction in somatic cell count in the milk of cows with intra-mammary infections of Staphylococcus aureus. Niacin improved the efficiency of glucose metabolism and, supplementation at $12 \mathrm{~g} /$ day reduced blood levels of triglycerides and $\beta$-hydroxybutyric acid, and thereby ketosis occurrence (Ghorbani et al., 2008). Kaur et al., (2003) reported improved conception rates in cows supplemented with niacin at $6 \mathrm{~g} /$ day. When niacin was supplemented in the rumen-protected form, it caused peripheral vasodilation ('flushing') that reduced heat stress by reducing core body temperature (Wrinkle et al., 2012). Heat stress reduced the feed intake and milk yield by 15 to 30\% (Di Costanzo et al., 1997). Therefore rumen-protected niacin supplementation could nullify heat stress-induced reduction in the milk yield. Niacin, choline and Pantothenic acid, in rumen-protected form, improved the blood glucose levels (Pinotti et al., 2005). Therefore supplementation of these vitamins could produce beneficial results in ketosis. Biotin is involved in the synthesis of keratin and, biotin supplementation daily at a dose rate of $20 \mathrm{mg} / \mathrm{kg}$ body weight reduced sole ulcers. Hence, biotin could be regarded as a potential beneficial agent in laminitis therapy (Bergsten et al., 2003).

Table.1 B vitamin supplementation influenced milk yield and composition

\begin{tabular}{|l|l|l|}
\hline $\begin{array}{l}\text { Shaver and Bal, } \\
\mathbf{2 0 0 5}\end{array}$ & Vitamin, dose & Findings \\
\hline Graulet et al.,2007 & $\begin{array}{l}\text { Folic acid }(2.6 \mathrm{~g} / \mathrm{day}), \mathrm{B}_{12} \\
\text { (0.5 g/day) }\end{array}$ & $\begin{array}{l}\text { Higher total milk, protein and fat }(2.7, \\
0.13 \text { and } 0.10 \mathrm{~kg} / \mathrm{day}) \text { yield }\end{array}$ \\
\hline $\begin{array}{l}\text { Sacadura } \text { et al., } \\
\mathbf{2 0 0 8}\end{array}$ & $\begin{array}{l}\text { Rumen protected biotin, } \\
\text { folic acid, pantothenic acid } \\
\text { and pyridoxine blend }(3.2, \\
4,40, \text { and } 25 \mathrm{mg} / \mathrm{g} \\
\text { respectively) at } 3 \mathrm{~g} / \mathrm{day} / \mathrm{cow}\end{array}$ & Higher total milk, protein and fat yield \\
\hline $\begin{array}{l}\text { Karkoodi and } \\
\text { Tamizrad, 2009 }\end{array}$ & $\begin{array}{l}\text { Niacin at } 12,14 \text { and } 16 \\
\text { g/day/cow }\end{array}$ & $\begin{array}{l}\text { With } 14 \mathrm{~g} / \mathrm{day} / \mathrm{cow} \text {, there was higher milk } \\
\text { fat, protein yield; higher blood glucose; } \\
\text { lower } \beta \text { hydroxy butyrate }\end{array}$ \\
\hline $\begin{array}{l}\text { Rungruang } \text { et al., } \\
\mathbf{2 0 1 4}\end{array}$ & $\begin{array}{l}\text { Rumen protected niacin at } \\
4,8 \text { or } 12 \mathrm{~g} / \mathrm{day} / \mathrm{cow}\end{array}$ & No change in milk yield \\
\hline $\begin{array}{l}\text { Duplessis } \text { et al., } \\
\mathbf{2 0 1 4}\end{array}$ & $\begin{array}{l}\text { Intramuscular injection of } \\
\text { folic acid }(320 \mathrm{mg}) \text { and } \mathrm{B}_{12} \\
(10 \mathrm{mg}) \text { in early lactation }\end{array}$ & Improved milk protein yield \\
\hline
\end{tabular}




\section{B vitamin supplementation for high producing cows}

Some of the recent researches that reported the influence of B vitamin supplementation on milk yield and composition are summarized in Table 1. As folic acid is involved in the metabolism of single carbon units, it played a major role in the synthesis of methionine. Methionine is involved in the initiation step of protein synthesis. Tissues with a high rate of cell division (for e.g., hematopoietic cells, mammary gland cells) responded positively to folic acid supplementation. Bonomi et al., (1998) reported improved in milk production when biotin was supplemented at 10 to $20 \mathrm{mg} /$ day. Ferreira (2006) concluded that the improvement in milk yield through biotin supplementation was possible in high producing cows only. Choline is one of the important 'methyl donors' in the animal system along with folic acid and $\mathrm{B}_{12}$. In dairy cattle, the output of methylated compound through milk is high. Methionine along with other compounds that supply methyl group is likely to be in short supply, especially during the early lactation when the feed intake is considerably lower compared to the actual requirement. Supplementation of choline spared other methyl donors like methionine. Higher methionine availability within the body improved protein content in the milk. Pinotti et al., (2005) studied the effect of rumen-protected choline supplementation in transition cows and observed that it improved the efficiency of milk production, and lipid and methyl group metabolism in these cows. The high metabolic rates during lactation in high producing cows make it susceptible to marginal B vitamin deficiencies. NRC (2001) have quantified the ruminal escape percentage of biotin, folic acid, niacin, pantothenic acid, riboflavin, thiamine, pyridoxine and $\mathrm{B}_{12}$ as $100,3,6,22, \quad 1,52,100$ and 10\% respectively. This implied that the higher demands for certain vitamins that undergo ruminal degradation can only be met if they are supplemented in the rumen-protected or parenteral form. Fat-based encapsulation method is usually practiced when B vitamins are supplemented to high producing animals.

In conclusions, each rumen microbe has specific requirements for certain B vitamins. In the rumen, there is a phenomenon called as "cross-feeding of vitamins" between the rumen microbes through which, the $\mathrm{B}$ vitamins produced by certain microbes is utilized for the growth of others and viceversa. Supplementation of B vitamins improved the microbial growth and activity in the rumen, which further raised the host nutritional status. Apart from this, there was an improvement in the host immunity, health and milk production when $\mathrm{B}$ vitamins were fed in the rumen-protected form. The NRC (2001) calculated daily B vitamin requirement for a dairy cow (weighed $650 \mathrm{~kg}$ and produced $35 \mathrm{~kg}$ milk/day) as 41, 156, 289, $425,48,6,35$, and $0.6 \mathrm{mg}$ /day respectively for thiamin, riboflavin, niacin, pantothenic acid, pyridoxine, biotin, folic acid and B12. However, these values were extrapolated from the tissue level requirements of a lactating swine. Optimization of the dose of vitamins using rumen or, rumen simulation model followed by its validation through clinical trials are required for further improvement in productivity and nutrient utilization.

\section{References}

Baldwin, R. L., and Allison, M. J. 1983. Rumen metabolism. Journal of Animal Sciences. 57(2):461-477.

Bechdel, S. I., Honeywelland, H. E., Dutcher, R. A., and Knutsen, M. H. 1928. Synthesis of vitamin B in the rumen of cow. Journal of biological chemistry. 80: $231-238$ 
Bergsten, C., Greenough, P. R., Gay, J. M., Seymour, W. H., and Gay, C. C. 2003. Effects of biotin supplementation on performance and claw lesions on a commercial dairy farm. Journal of Dairy Science, 86, 3953-3962. doi:10.3168/jds.S00220302(03)74005-3

Bonomi, A., Bonomi, B.M., Quarantelli, A., Sabbioni, A., and Superchi, P. 1998. Dairy cattle ration integration with rumen-protected pyridoxine. Effects on milk production and reproductive efficiency (experimental report). 27, 201-211.

Cruyvagen, C. W., and Bunge, G. A. 2004. The effect of supplemental biotin in dairy cow diets on fibre fermentation patterns as measured by in vitro gas production. South African Journal of Animal Science. 34: 68-70

Di Costanzo, A., Spain, J.N. and Spiers, D.E. 1997. Supplementation of nicotinic acid for lactating Holstein cows under heat stress conditions. Journal of Dairy Science. 80(6): 1200-1206.

Niehoff I., Huther, L., Lebzien, P., and Flachowsky, G. 2013. The effect of a Niacin supplementation to different diets on ruminal fermentation and flow of nutrients to the duodenum of dairy cows. Applied Agricultural and Forestry Research.63.143-154.

Duplessis, M., Girard, C.L., Stanschi, D.E., Lefebvre, D.M., and Pellerin, D. 2012. Folic acid and vitamin B12 supplement enhances energy metabolism of dairy cows in early lactation. ADSA Abstract M319.

Ferreira, G. 2006. Effect of biotin supplementation on the metabolism of lactating dairy cows. Ph.D. Dissertation, The Ohio State Univ., Columbus.

Fletcher, D. W. 1956. Studies on the growth requirements of a cellulolytic coccus from the bovine rumen. Ph.D. Thesis, State College of Washington, Pullman, Washington.

Ghorbani, B., Vahdani, N., and Zerehdaran, S. 2008. Effects of Niacin on Milk Production and Blood Parameters in Early Lactation of Dairy Cows. Pakistan Journal of Biological Sciences. 11: 1582-1587

Graulet, B., Matte, J. J., Desrochers, A., Doepel, L., Palin, M. F., and Girard, C. L. 2007. Effects of dietary supplements of folic acid and vitamin $\mathrm{B}_{12}$ on metabolism of dairy cows in early lactation. Journal of Dairy Science. 90(7):3442-3455.

Karkoodi, K., and Tamizrad, K. 2009. Effect of niacin supplementation on performance and blood parameters of Holstein cows. South African Journal of Animal Science. 39(4):349-354

Kaur, H., Chawla, R., and Kewalramani, N. 2003. Need to review B vitamin requirement in ruminants. 55(10):6870

MacLeod, R. A., and Murray, J. F. 1956. Some factors affecting cellulose digestion by rumen microorganisms in vitro. Journal of Nutrition, 60, 245 259.

NRC. 2001. Nutrient Requirements of Dairy Cattle. 7th ed. National Academy of Science, Washington, DC, USA.

Orpin CG, Greenwood Y. 1986. Nutritional and germination requirements of the rumen chytridiomycete. Neocallimastix patriciarum. Transactions of the British Mycological Society. 86(1):103-109.

Pinotti, L., Campagnoli, A., Dell, Orto, V., and Baldi, A. 2005. Choline: Is there a need in the lactating dairy cow? Livestock Production Science. 98: 149-152.

Rungruang, S., Collier, J.L., Rhoads, R.P., Baumgard, L.H., de Veth, M.J. and 
Collier, R.J. 2014. A dose-response evaluation of rumen-protected niacin in thermoneutral or heat-stressed lactating Holstein cows. Journal of dairy science, 97(8): 5023-5034.

Sacadura, F. C., Robinson, P. H., Evans, E. and Lordelo, M. 2008. Effects of a ruminally protected B-vitamins supplementation on milk yield and composition of lactating dairy cows. Animal Feed Science and Technology 144: 111-124.

Sato, S., Hori, H., and Okada, K. 1999. Effect of vitamin B2 on somatic cell counts in milk of clinical Staphylococcus aureus mastitis. Journal of Veterinary Medical Science. 61(5):569-571.

Schwab, E. C., Schwab, C. G., Shaver, R. D., Girard, C. L., Putnam, D. E. and Whitehouse, N. L. 2006. Dietary forage and nonfiber carbohydrate contents influence B-vitamin intake, duodenal flow, and apparent ruminal synthesis in lactating dairy cows. Journal of Dairy Science. 89(1): 174187.

Shaver, R. D., and Bal, M. A. 2000. Effect of dietary thiamin supplementation on milk production by dairy cows. Journal of Dairy Sci. 83(10):23352340

Tamizrad, K., and Karkoodi, K. 2009. Effect of niacin supplementation on performance and blood parameters of Holstein cows. South African J of Ani Sci. 39(4):349-354

Wrinkle, S. R., Robinson, P. H., and Garret, J. E. 2012. Niacin delivery to the intestinal absorption site impacts heat stress and productive response of high producing dairy cows during hot conditions. Animal feed science and technology. 175:33-47

\section{How to cite this article:}

Ashwin, K., Varsha Paladan, Sandeep Uniyal, Jatin Kumar Sahoo, Shahla Perween, Mokshata Gupta and Asmita Singh. 2018. An Update on B Vitamin Nutrition for Cattle. Int.J.Curr.Microbiol.App.Sci. 7(07): 188-192. doi: https://doi.org/10.20546/ijcmas.2018.707.023 